\title{
PREVENTING TRANSBOUNDARY HARM FROM INVASIVE ALIEN SPECIES*
}

\section{ABSTRACT}

The problem of invasive alien species (IAS) is the second biggest threat to biodiversity after loss of habitat. Although customary international law obliges States to prevent transboundary environmental harm such as IAS, international law does not clearly articulate these obligations in this context. A potentially helpful mechanism lies in the use of transboundary environmental impact assessment and risk analysis. However, the operation of these processes, within international environmental law, international quarantine law, and international trade law has generated obligations that largely remain soft, ill-defined and inconsistent. This situation is counterproductive to preventing or minimizing transboundary harm caused by IAS.

\section{INTRODUCTION}

The ruddy duck is a small reddish-brown duck, native to North America. ${ }^{1}$ In the 1940s, the Wildfowl and Wetlands Trust, a United Kingdom organization devoted to the conservation of wetlands, imported breeding pairs of ruddy ducks from the United States for study purposes. ${ }^{2}$

The first ruddy ducklings hatched in the United Kingdom in 1949 and, by 1960, a number of specimens had escaped captivity and started breeding in the wild. Twenty-three years later, the ruddy duck was sighted in Spain and by 1990-1991 reports began emerging of hybridization between ruddy ducks

\footnotetext{
${ }^{1}$ DEFRA, Protecting the White-Headed Duck, Fact Sheet (undated), at 3.

${ }^{2}$ L.L. Shurtleff and C. Savage, The Wood Duck and the Mandarin: The Northern Wood Ducks (University of California Press, 1996), at 206.
} 
and Spanish white-headed ducks. ${ }^{3}$ Within five years of these reports, the ruddy duck had spread to eighteen European countries. ${ }^{4}$ Both the ruddy duck and its offspring are more dominant and aggressive than native white-headed ducks and populations of ruddy ducks in the United Kingdom are regarded as the most significant threat to the survival of the white-headed duck in Europe. $^{5}$

At the time the ruddy duck spread from the United Kingdom to Spain, it was not considered 'invasive' in the United Kingdom; and it was only in 2003, after appeals by Spain that the United Kingdom agreed in principle to eradicate the ruddy duck from UK territory. ${ }^{6}$ This case is but one example of how alien species, not invasive in a 'carrier State', can nevertheless be a source of transboundary environmental harm. Other examples include species introduced for biocontrol, such as the insect Cactoblastis cactorum. Cactoblastis was introduced into the Caribbean in the early 1960s as a weed biological control agent and has now spread throughout the Caribbean region threatening the centre of biodiversity for Opuntia-cacti in Mexico. ${ }^{7}$

The purpose of this paper is to examine the nature and extent of obligations imposed upon States to prevent transboundary harm caused by invasive alien species (IAS). The discussion commences with the problem of IAS, and then considers obligations and restraints that States face in preventing transboundary harm from IAS. The paper concentrates on the deliberate introduction of species in the context of three inter-linked regimes: the international environmental law regime, the international quarantine regime, ${ }^{8}$ and the international trade law regime.

\footnotetext{
${ }^{3}$ Ibid., 206-7.

${ }^{4}$ Ibid.

${ }^{5}$ Ibid.

${ }^{6}$ See DEFRA, n. 1 above, at 6.

${ }^{7}$ G. Zimmermann et al., 'The Renowned Cactus Moth, Cactoblastis cactorum: Its Natural History and Threat to Native Opuntia floras in Mexico and the United States of America' 6:5 Diversity and Distributions (2006), 259.

${ }^{8}$ The phrase 'international quarantine' refers to the collection of instruments, dealing with human health, and plant and animal health and protection, that constitute a quarantine system
} 
Although customary international law generally obliges States to prevent transboundary harm, international law also lacks specific obligations with respect to transboundary harm caused by IAS. The discussion explores the role of environmental impact assessment and risk analysis as a means of preventing or minimizing transboundary impacts of IAS. It is concluded that these processes are not used to their full potential and that more detailed guidance is required together with greater cooperation among States and among regimes.

\section{THE PROBLEM OF INVASIVE ALIEN SPECIES}

Alien species are species that have been introduced to a new location, outside their natural past or present distribution. ${ }^{9}$ From the viewpoint of protection of biodiversity, invasive alien species are alien species whose introduction and spread threatens biological diversity. ${ }^{10}$ Not all alien species pose a threat to biodiversity $^{11}$ and alien species often serve useful social and economic purposes, as, for instance, in agriculture or aquaculture production. ${ }^{12}$

based on international collaboration, cooperation and harmonization designed to prevent the spread of pests and diseases across international boundaries. Moreover, the term 'international quarantine' also encompasses the whole complex of international and domestic instruments, laws and measures.

${ }^{9}$ See 'Guiding Principles for the Prevention, Introduction and Mitigation of Impacts of Alien Species that Threaten Ecosystems, Habitats or Species' adopted as part of Decision VI/23, found in Report of the Sixth Meeting of the Conference of the Parties to the Convention on Biological Diversity (UNEP/CBD/COP/6/20, 23 September 2002). See in particular the definitions in footnote (57) paragraph (i).

${ }^{10}$ Ibid., definitions in footnote (57), paragraph (ii).

11 J. A. McNeely, 'The Great Reshuffling: How Alien Species Help Feed the Global Economy', in O. Sandlund et al., (eds) Proceedings of the Norway/UN Conference on Alien Species Trondheim July 1995 (Directorate for Nature Management Trondheim, 1996), at 53; Convention on Biological Diversity SBSTTA, 'Development of Guiding Principles for the Prevention of Impacts of Alien Species by Identifying Priority Areas of Work on Isolated Ecosystems and by Evaluating and Giving Recommendations for the Further Development of the Global Invasive Species Programme’ (UNEP/CBD/SBSTTA/4/8, 15 February 1999).

${ }^{12}$ Department of the Environment Food and Rural Affairs (DEFRA), Review of Non-Native Species Policy Report of the Working Group (DEFRA, 2003), at 8; and see T. Low, Feral Future (Viking Victoria, 1999), at 42. 
Nevertheless, while some alien species may provide benefits, the problem of invasive alien species has been described by the International Union for Conservation of Nature (IUCN) ${ }^{13}$ as 'one of the major threats to biological diversity', with their impacts considered to be as damaging as loss of habitat. ${ }^{14}$ Biodiversity is defined in Article 2 of the Convention on Biological Diversity $(\mathrm{CBD})^{15}$ as 'the variability among living organisms...[including]...diversity within species, between species and of ecosystems.' Therefore, in order to protect biodiversity, it is necessary to protect individual species, the variability amongst species, as well as their interrelationships to each other and their ecosystems.

Alien species can threaten or harm biodiversity in innumerable ways, including direct predation on native species, ${ }^{16}$ modifying habitat, ${ }^{17}$ introducing pests and diseases ${ }^{18}$ and, as indicated by the case of the ruddy duck, hybridizing with native species. ${ }^{19}$ Studies indicate that the pressures of IAS are propelling species to extinction, leading to loss of biodiversity. ${ }^{20}$ Due to the difficulty of eradicating IAS, preventative mechanisms are often seen

\footnotetext{
${ }^{13}$ The International Union for the Protection of Nature was founded on 5 October 1948 to help find solutions for the world's most pressing environment and development issues.

${ }^{14}$ IUCN, 'Guidelines For the Prevention of Biodiversity Loss Caused by Alien Invasive Species’, Species Survival Commission of IUCN (IUCN, 2000), section 1.

${ }^{15}$ Convention on Biological Diversity (Rio de Janeiro, 5 June 1992) (CBD). The Convention had 191 Parties as of February 2009.

${ }^{16}$ C. Brown 'Tilapia and the Environment',4:2 TED Case Studies (1995), case no 208, available <http://www.american.edu/TED/tilapia.htm>.

${ }^{17}$ United Nations Environment Programme (UNEP), Fact-sheet on 'Yellow-eyed Penguin' (UNP, undated), available at $\quad<$ http://www.unepwcmc.org/species/data/species_sheets/yellowey.htm>.

${ }^{18}$ C. Shine et al., A Guide to Designing Legal and Institutional Frameworks on Alien Invasive Species (IUCN, 2000), at paragraph 1.4.

${ }^{19}$ Subsidiary Body on Scientific Technical and Technocological Advice, 'Pilot Assessments: The Ecological and Socio-Economic Impact of Invasive Alien Species on Island Ecosystems' (UNEP/CBD/SBSTTA/9/INF/335, November 2003).

${ }^{20}$ G. Sherley and S. Lowe, 'Towards a regional invasive species strategy for the South Pacific: Issues and options', in G. Sherley (ed) Invasive species in the Pacific: A Technical Review and Draft Regional Strategy (SPREP, 2000), at 7-8.
} 
as the most effective management option. ${ }^{21}$ In this respect, border controls by way of quarantine regulation have an important role to play. ${ }^{22}$

\section{BORDER CONTROLS AND INVASIVE ALIEN SPECIES}

Measures implemented by way of border controls can comprise outright prohibitions on the movement of goods or people, or less drastic measures such as treatments, permits and licensing. Minimizing accidental introductions often involves inspecting shipments to detect and intercept unauthorized entry of species. ${ }^{23}$

However, the efficacy of border controls has limitations. The vast array of pathways by which species may be introduced, including the various media associated with international trade and transport, ${ }^{24}$ challenges even the best systems. ${ }^{25}$ Moreover, border controls will be ineffective where the species is capable of spreading of its own volition. Quarantine measures, for example, will have little control over the flight path of a duck. An alternative option lies in the implementation of regimes that take into account the impact of alien species on neighbouring States and ecosystems - essentially States taking into account the potential for transboundary harm from IAS.

'Transboundary harm' is defined in the Draft Articles for the Prevention of Transboundary Harm from Hazardous Activities as: 'harm caused in the

${ }^{21}$ J. A. McNeely et al., Global Strategy on Invasive Alien Species, A Global Strategy on Invasive Alien Species (IUCN, 2001), at paragraph 6.2.

${ }^{22}$ See CBD Guiding Principles, n. 9 above, Principle 7.

${ }^{23}$ Australian Quarantine Act 1908 (Commonwealth), section 4.

${ }^{24}$ Australian Academy of Science, 'Submission to the review of the Australian Quarantine Inspection Service (Australian Academy of Science, March 1996), at paragraph 3.1.1, available at <http://www.science.org.au/reports/aqiscont.htm>; see also generally S. Burgiel et al., Invasive Alien Species and Trade: Integrating Prevention Measures and International Trade Rules (Center for International Environmental Law (CIEL), January 2006).

${ }^{25} \mathrm{~J}$. Mumford, 'Economic Issues Related to Quarantine in International Trade' 29:3 European Review of Agricultural Economics (2002), 329 at 330; GISP, 'The Internet as a Pathway for IAS' (GISP, 2004), available at

$<$ http://www.gisp.org/publications/brochures/FactsheetInternetPathway.pdf>. 
territory of or in other places under the jurisdiction or control of a State other than the State of origin, whether or not the States concerned share a common border' $^{26}$ In the context of invasive alien species, this definition is sufficiently broad to include all manner of harm, including the export of consignments contaminated by pests and diseases ${ }^{27}$ as well as the importation of species, such as ruddy duck and Cactoblastis cactorum that 'escape' into neighbouring States and beyond.

\section{TRANSBOUNDARY HARM AND INVASIVE ALIEN SPECIES}

International environmental law obligations to protect the environment and, more explicitly, biodiversity from transboundary harm may be drawn from customary international law and treaties; while more specific objectives with respect to protecting biodiversity from transboundary harm generated by IAS may be gathered from soft law instruments, such as guidelines and codes of conduct. $^{28}$

\subsection{International Law and IAS}

${ }^{26}$ Draft Articles for the Prevention of Transboundary Harm from Hazardous Activities, Article 2 (c). International Law Commission, 'Report of the International Law Commission, Fifty-third Session' (23 April-1 June and 2 July - 10 August 2001), found in Official Records of the General Assembly, Fifty-sixth Session, Supplement No. 10 (A/56/10, 2001). The text was adopted by the International Law Commission at its fifty-third session in 2001 and submitted to the General Assembly as a part of the Commission's report covering the work of that session.

27 See Australian Academy of Science, n. 24 above, at paragraph 3.3.

${ }^{28}$ For example, see the FAO Code of Conduct for Responsible Fisheries (1995) and the ICES Code of Practice on the Introductions and Transfers of Marine Organisms (2005). The FAO Code of Conduct for Responsible Fisheries was adopted at the $28^{\text {th }}$ session of the Food and Agriculture Organization (FAO) on 31 October 1995 and is supported by nine Technical Guidelines and four Plans of Action. See FAO Code of Conduct for Responsible Fisheries (FAO, Rome, 1995); see discussion in P. Mace and W. Gabriel, 'Evolution, Scope and Current Applications of the Precautionary Approach in Fisheries' in Proceedings $5^{\text {th }}$ NMFS NSAW Tech. Mem. (NMFS-F/SPO-40, 1999), at 65. ICES is the International Council for the Exploration of the Sea. It promotes and coordinates marine research in the North Atlantic Ocean. See ICES, Code of Practice on the Introductions and Transfers of Marine Organisms (ICES, 2005), available

at <http://www.ices.dk/reports/general/2004/ices\%20code\%20of\%20practice\%202005.pdf>. 
In accordance with customary international law, States have a duty to prevent, reduce and control environmental harm ${ }^{29}$ and a duty to cooperate to mitigate transboundary environmental risks. ${ }^{30}$ In particular, no State has the right to use or permit the use of its territory in such a manner as to cause serious injury to the territory of another State. ${ }^{31}$ Customary international law also obliges States to co-operate with respect to environmental matters. ${ }^{32}$ Although the actual consent of the other party may not be needed before one State undertakes an activity, prior notification is required to allow time for deliberations between the States.

Both of these customary international law duties find expression in the CBD. Article 3 of that convention, for example, specifies that:

States have ... the sovereign right to exploit their own resources ... and the responsibility to ensure that activities within their jurisdiction or control do not cause damage to the environment of other States or of areas beyond the limits of national jurisdiction.

Article 5 provides that:

Each Contracting Party shall, as far as possible and as appropriate, cooperate with other Contracting Parties ... in respect of areas beyond national jurisdiction ... for the conservation and sustainable use of biological diversity.

Customary international law duties to prevent transboundary harm and to cooperate are, therefore, formulated in a more categorical sense within the CBD, specifically targeting the protection of biodiversity. In effect, customary international law notions of environmental harm now extend

${ }^{29}$ Trail Smelter arbitration (United States $v$ Canada) Initial Decision 16 April 1938 (1939) 33 AJIL 182; Final Decision 11 March 1941 (1941), 35 AJIL 684; Corfu Channel (United Kingdom v Albania) Judgment, Merits, [1949] ICJ Reports 4 at 18 and 23.

${ }^{30}$ Affaire du Lac Lanoux arbitration (Spain v France) (1957), 24 ILR 101, at 141and 142.

${ }^{31}$ See Corfu Channel, n. 29 above, at 22; Advisory Opinion on The Legality of the Threat of Use of Nuclear Weapons, [1996] ICJ Reports 226, at paragraph 2.

${ }^{32}$ See Affaire du Lac Lanoux arbitration n. 30 above, at 128-130. 
beyond pollution control and governance of shared resources, ${ }^{33}$ to include harm to biodiversity. This means that many obligations of the CBD relating to the protection of biodiversity from transboundary harm are manifestations of general customary international law duties and are binding on States whether or not they are party to the CBD.

Perhaps somewhat less clear is the scope and nature of obligations on States with respect to specific obligations, such as the protection of biodiversity from invasive alien species. Customary international law does not expressly refer to IAS. Yet, to the extent that IAS threaten or harm biodiversity, the introduction and spread of those species from one territory to another can breach customary international law. In addition, States can also breach customary international law where they have not cooperated by way of notification, communication and consultation with respect to their IAS regimes. $^{34}$

Despite the potentially wide ambit of the duty to prevent environmental harm, the extent of liability imposed by the duty is not yet settled. ${ }^{35}$ While the formulation of the duty stresses prevention, this is not borne out by State practice. In the context of transboundary pollution one commentator has said:

... the principle is often considered to be limited to ... a duty by the source State to 'undertake due diligence' to prevent significant or substantial transboundary pollution ... ${ }^{36}$

${ }^{33}$ X. Hanquin, Transboundary Damage in International Law (Cambridge University Press, 2003), at 3-10.

${ }^{34}$ G.M. Sikoyo and L. Goldman, 'Assessing the Assessments: Case Study of an Emergency Action Plan for the Control of Water Hyacinth in Lake Victoria', 23:3 International Journal of Water Resources Management (2007), at 443.

35 J.H. Knox 'The Myth and Reality of Transboundary Environmental Impact Assessment', 96:2 The American Journal of International Law (2002), 291, at 293.

${ }^{36}$ N.D. Hall, 'Transboundary Pollution: Harmonizing International and Domestic Law', 40:4 University of Michigan Journal of Law Reform (2007), 681, at 700; P Okawa, 'The Legacy of Trail Smelter in the Field of Transboundary Air Pollution', in R. Bratspies and R. Miller (eds), Transboundary Harm in International Law (Cambridge University Press, 2006), at 197. 
This limitation reflects the practicality that resource restraints often exert on a State's response to environmental problems. ${ }^{37}$ Parallel developments are occurring with respect to the protection of biodiversity from IAS.

Article 8(h) of the CBD imposes overarching obligations on the contracting parties, 'to prevent the introduction of or control or eradicate those alien species which threaten ecosystems, habitats or species'. The Article is prefaced by the phrase 'as far as possible and as appropriate' which means that States need only comply with the article in accordance with their resource constraints and as befits the circumstances. Furthermore, Article 8(h) is a framework provision that requires detail on how it is to become operational. The Article also does not specifically address the issue of transboundary harm from IAS. However, if Articles 3 and 5 of the CBD are read in conjunction with Article 8(h), it is apparent that States are under an obligation to ensure that as far as possible their activities do not 'cause damage to the environment of other States'.

An important soft law instrument that fleshes out Article 8(h) is the CBD Guiding Principles for the Prevention, Introduction and Mitigation of Impacts of Alien Species that Threaten Ecosystems Habitats or Species (CBD Guiding Principles, or Guiding Principles). ${ }^{38}$

\subsection{Prevention versus Minimization of Transboundary Harm}

The CBD Guiding Principles comprise 15 principles designed to enhance and harmonize State practice with respect to IAS regulation. They are underpinned by a three-tiered approach focussed on preventing introductions followed by eradication and control measures. ${ }^{39}$ In order to prevent and minimize introductions, the Guiding Principles stress a managed risk

${ }^{37}$ See generally L. Glowka and C. de Klemm, 'International Instrument, Processes and Nonindigenous Species Introductions - Is a Protocol Necessary?', 26:6 Environmental Policy and Law (1996), 247.

${ }^{38}$ See CBD Guiding Principles, n. 9 above, Guiding Principles 1-15.

${ }^{39}$ Ibid., Principle 2. 
approach that evaluates and manages the risk of alien species to become invasive ${ }^{40}$ Managing the risk is important because, unless the risk relates to the introduction of pests and diseases, a State is unlikely to decide that it will not accept any risk and block out species' imports. States are conscious of the fact that a generalized no-risk or even least-risk approach would be seen as unjustifiably harmful to international trade. ${ }^{41}$

Under the managed risk approach, risks (in this case from IAS) are assessed on the basis of whether they can co-exist with members' needs, expectations and resource constraints. States, therefore, regard the managed risk approach as a way of balancing competing claims including those between protection of biodiversity and free trade. The situation is no different with respect to prevention of transboundary harm.

The CBD Guiding Principles address the problem of transboundary harm in a number of ways. First, the Principles call for management along ecosystem lines, ${ }^{42}$ in accordance with the ecosystem approach adopted by the Conference of the Parties (COP) to the CBD. ${ }^{43}$ Principle 3 of CBD Decision $\mathrm{V} / 6$ specifies that '[e]cosystem managers should consider the effects ... of their activities on adjacent and other ecosystems.' This principle, therefore, applies on a spatial scale to ecosystems that straddle political boundaries as well as ecosystems located further afield. In the case of IAS, such as the ruddy duck or Cactoblastis cactorum, the importing State should have regard to the effect of the species on ecosystems consistent with the species' likely range. Similarly, where States share ecosystems, such as transboundary lakes,

\footnotetext{
${ }^{40}$ Ibid., Principles 10 and 11 and Footnote 57 (vii).

${ }^{41}$ M.E. Nairn et al., Australian Quarantine: A Shared Responsibility (Department of Primary Industries and Energy, Canberra 1996), at paragraphs 2.1 and 3.2.2.

${ }^{42}$ CBD Guiding Principles, n. 9 above, Principle 3.

${ }^{43}$ The Ecosystem Approach was adopted by the Conference of the Parties to the CBD in Decision V/6. See Decision V/6, 'Ecosystem Approach', found in Report of the Fifth Meeting of the Conference of the Parties to the Convention on Biological Diversity (UNEP/CBD/COP/5/23, 22 June 2000), at 103.
} 
they would need to consider impacts on the biodiversity of the entire lake prior to introducing alien species. ${ }^{44}$

Second, specific recommendations in Guiding Principle 4 of the CBD Guiding Principles (on the role of States) encourage States to consider the likelihood of transboundary harm when they are importing alien species and also to cooperate to minimize the harmful impacts of those species. Examples of transboundary harm referred to in the Principle include:

(a) The intentional transfer of an invasive alien species to another State (even if it is harmless in the State of origin);

(b) The intentional introduction of an alien species into their own State, if there is a risk of that species subsequently spreading ... into another State and becoming invasive;

(c) Activities that may lead to unintentional introductions, even where the introduced species is harmless in the State of origin.

This principle and Principle 3 of Decision V/6 do not impose absolute prohibitions on the generation of transboundary harm. Rather the principles require that the effect of environmental damage be considered and that States cooperate to 'minimize' harmful impacts of IAS. These developments reflect the broader view that regimes dealing with transboundary harm are moving towards accommodation of regulatory models, rather than providing for outright prevention of harm. ${ }^{45}$

In the case of chemical pollutants, one reason proposed for the devolution of regulatory models stems from difficulties associated with attributing liability. Pollution for example may not manifest itself for many years, creating uncertainty with respect to causation and making it problematic to determine

44 Convention for the Establishment of the Lake Victoria Fisheries Organization 1994, preamble (Kisumu, 30 June 1994). The Convention entered into force 24 May 1996.

45 See P. Okawa, n. 36 above, at 198-9. 
compensation. ${ }^{46}$ Similarly in the context of IAS, an important area of concern centres on the time-lag between introductions and manifestation of a species' invasive qualities. Studies indicate that average lag times of 147 years are not unusual, $^{47}$ with some reports increasing this figure to 170 years. $^{48}$ Furthermore, IAS are living beings. Even if introduction of the species ceases, the species can continue to reproduce and increase its range for many years. $^{49}$

For States to take into account the potential for transboundary harm from IAS they need to consider the following: evaluation of alien species for their potential to cause transboundary harm; notification and exchange of information with other States; and implementation of procedures that take into account the effects of proposed introductions on other States, including consultation with them. ${ }^{50}$ Two increasingly popular means of incorporating these requirements are the use of Environmental Impact Assessment (EIA) and risk analysis.

\subsection{Environmental Impact Assessment and Risk Analysis}

EIA is described within the CBD as a process 'of evaluating the likely environmental impacts of a proposed project or development, taking into account inter-related socio-economic cultural and human-health impacts, both beneficial and adverse'. ${ }^{51}$ Risk analysis is a process that evaluates the

\footnotetext{
46 Ibid.

${ }^{47}$ R. Wittenberg, An Inventory of Alien Species and Their Threat to Biodiversity and Economy in Switzerland, in CABI Bioscience Switzerland Centre report to the Swiss Agency for Environment, Forests and Landscape (SAEFL, 2005), at 26.

48 See T. Low, n. 12 above, at 216-17.

${ }^{49}$ G. Wilson et al., Pest Animals in Australia (Kangaroo Press and Bureau of Rural Resources, 1992).

50 See J.H. Knox, n. 35 above, at 295.

${ }^{51}$ CBD Decision VIII/28, 'Impact Assessment: Voluntary Guidelines on Biodiversityinclusive Impact Assessment' (UNEP/CBD/COP/8/31, 26 June 2006), at paragraph 5; R. Slootweg, et al., Biodiversity in EIA and SEA Background Document to CBD Decision VIII/28: Voluntary Guidelines on Biodiversity-Inclusive Impact Assessment (Commission for Environmental Assessment The Netherlands, April 2006), at chapter 5.
} 
likelihood of an event occurring and its ramifications in the midst of uncertainty. ${ }^{52}$

Although EIA and risk analysis are not identical, they have much in common, for they can both be used to evaluate 'the likely consequences of environmental change, ${ }^{53}$ and assist planners, regulators and decision-makers to make informed choices. ${ }^{54}$ The processes were developed from State practice and designed to provide decision-makers with information allowing them to balance interests, such as development, environmental protection and social and economic factors. ${ }^{55}$ Consequently, the processes are not designed to provide a 'right' or 'wrong' solution. The ensuing discussion refers to both EIA and risk analysis, although international instruments may refer only to one or the other.

\subsubsection{Transboundary Environmental Impact Assessment/Risk Analysis}

Article 14 of the CBD stipulates that with respect to the protection of biodiversity, parties should as far as possible and as appropriate:

(a) Introduce appropriate procedures requiring environmental impact assessment of its proposed projects that are likely to have significant adverse effects on biological diversity ...;

(b) Introduce appropriate arrangements to ensure that the environmental consequences of its programmes and policies that are likely to have significant adverse impacts on biological diversity are duly taken into account;

(c) Promote, on the basis of reciprocity, notification, exchange of information and consultation on activities under their jurisdiction or control which are

\footnotetext{
52 J. Mumford, 'Environmental Risk Evaluation in Quarantine Decision Making' in K. Anderson, C. McRae and D. Wilson (eds), The Economics of Quarantine and the SPS Agreement (Centre for International Economic Studies Adelaide and AFFA Biosecurity Australia, 2001), at 353; M. Nunn, 'The analytical foundation of quarantine risk analysis', in K. Anderson, C. McRae and D. Wilson (eds), ibid., at 30; A. Brookes, 'Environmental risk assessment and risk management', in P. Morris and R. Therivel (eds), Methods of Environmental Impact Assessment (Spon Press, 2001), 362.

${ }^{53}$ P. Wathern, 'An Introductory Guide to EIA', in P. Wathern (ed) Environmental Impact Assessment Theory and Practice (Unwin Hyman, 1988), 85.

${ }^{54}$ O. Demidova and A. Cherp, 'Risk Assessment for Improved Treatment of Health Considerations in EIA' 25 Environmental Impact Assessment Review (2005), 411, at 413.

${ }^{55}$ See P. Wathern, n. 53 above, at 19-20; and J.H. Knox, n. 35 above, at 298.
} 
likely to significantly affect adversely the biological diversity of other States or areas beyond the limits of national jurisdiction, by encouraging the conclusion of bilateral, regional or multilateral arrangements, as appropriate; ${ }^{56}$

Sub-paragraphs (a) and (b) which refer to EIA, impose positive obligations on States to conduct EIA for activities that can harm biodiversity. However, subparagraph (c) which specifically addresses the issue of transboundary harm contains soft obligations that extend only to notification, exchange of information and consultation. These provisions undoubtedly reflect the 'real world', where a State that is unable, for reasons of capacity or political will, to address the issue of IAS that threaten domestic interests, will also be unlikely to take into account transboundary issues.

In the same vein, Guiding Principles 10 (on intentional introductions) and 11 (on unintentional introductions) of the CBD Guiding Principles, specify the use of risk analysis and EIA to evaluate IAS but do not mention transboundary impacts. Only in Guiding Principle 4 (on the role of States) do we find the necessity of notification, exchange of information and other cooperative efforts to minimize the risk of transboundary harm from IAS.

The ecosystem approach as set out under the CBD regime envisions tighter guidelines with respect to transboundary EIA. Principle 3 of CBD Decision V/6 indicates that EIA should be carried out 'for developments that may have substantial environmental impacts ... [including] ... potential offsite impacts'. In the case of IAS, this would incorporate consideration of impacts located beyond the site of initial introduction of an alien species, such as consideration of the ruddy duck 'escaping' from the UK to Spain. Tighter guidelines are also found in one other instrument that grapples with

\footnotetext{
${ }^{56}$ See CBD, n. 15 above, Article 14(1)(c).
} 
evaluation of transboundary harm for alien species - the Cartagena Protocol on Biosafety to the CBD (Cartagena Protocol). ${ }^{57}$

The Cartagena Protocol was negotiated to regulate the safe handling and transfer of a particular type of alien species - living modified organisms (LMOs) ${ }^{58}$ By its very nature an LMO is an alien species, for it does not have a natural past or present distribution, as it exists only through human intervention. Read together, Article 15(2) and Annex III of the Cartagena Protocol specify that the party importing LMOs should ensure that risk assessments are carried out prior to importation, that take into account:

... the potential adverse effects of living modified organisms on the conservation and sustainable use of biological diversity in the likely potential receiving environment. ${ }^{59}$

Although there is no specific mention of transboundary risk assessment, the reference to the 'likely potential receiving environment' is important because elsewhere the Protocol refers to the 'Party of import ${ }^{60}$ - which is the party that has authorized a deliberate introduction of an LMO. ${ }^{61}$ The 'likely potential receiving environment' has been described as 'an ecosystem or habitat, including humans and animals, which is likely to come into contact with a released organism'. ${ }^{62}$ Such a concept incorporates the territorial reach of an LMO and is notionally wider than the 'Party of import'.

\footnotetext{
${ }^{57}$ Cartagena Protocol on Biosafety to the Convention on Biological Diversity (Montreal, 29 January 2001) (Cartagena Protocol), Articles 15 and 16. The Protocol had 153 Parties as of February 2009.

${ }^{58}$ Ibid., Article 3(g). See also S.W. Burgiel, 'The Cartagena Protocol on Biosafety: Taking the Steps from Negotiation to Implementation’, 11:1 RECIEL (2002), 53.

${ }^{59}$ Cartagena Protocol, ibid., Annex III, Article 1) Objectives).

${ }^{60}$ Ibid., Articles 6, 7, 8, 9, 10, 11 and 12.

${ }^{61}$ Ibid., Article 3.

${ }^{62}$ UNEP, International Technical Guidelines for Safety in Biotechnology, Division of Biosafety and Biotechnology (UNEP, April 2001), Annex 2 (Glossary). The Guidelines were adopted by the Global Consultation of Government-designated Experts, hosted by the government of Egypt in Cairo from 11 to 14 December 1995, and are available at <www.biosafetyprotocol.be/UNEPGuid/UNEP_02.html>.
} 
This arguably means that the Cartagena Protocol obliges States to implement transboundary risk assessment with respect to LMOs. States need to evaluate the likelihood of an adverse impact on biodiversity by taking into account 'the level and kind of exposure of the likely potential receiving environment to the living modified organism'. ${ }^{63}$ In order to carry out these requirements, the importing State would need at least to have considered objections and information supplied by other States.

At present, the extent to which States should use EIA and/or risk analysis to prevent or minimize transboundary harm is far from settled. Yet, it is possible that transboundary EIA and/or risk analysis have become part of customary international law. ${ }^{64}$ If this is the case, States would be obliged to undertake transboundary EIA and/or risk analysis independently of recommendations found elsewhere.

\section{TRANSBOUNDARY EIA/RISK ANALYSIS AND CUSTOMARY INTERNATIONAL LAW}

The negotiation of bilateral, regional and multilateral arrangements specifying the use of transboundary EIA and/or risk analysis is becoming increasingly common. ${ }^{65}$ For example, the 1991 Convention on Environmental Impact Assessment in a Transboundary Context ${ }^{66}$ was negotiated to regulate transboundary environmental impacts for a range of activities that are set out in Appendix 1 of the Convention. ${ }^{67}$ The Convention is predicated on

\footnotetext{
${ }^{63}$ Cartagena Protocol, n. 57 above, Annex III, Article 7(b).

${ }^{64}$ See J. H. Knox, n. 35 above; and N.D. Hall, n. 36 above, at 700-723.

${ }^{65}$ J.H. Knox, ibid. See also Protocol to the Treaty for the Establishment of the East African Community for Sustainable Development in the Lake Victoria Basin, (Arusha, 29 November 2003), available at $<$ http://www.ecolex.org/server2.php/libcat/docs/multilateral/en/TRE002034.doc >. The Protocol presently has three parties.

${ }^{66}$ Convention on Environmental Impact Assessment in a Transboundary Context (Espoo, 25 February 1991). As of February 2009 the Convention had 42 parties.

${ }^{67}$ Ibid., Article 4.
} 
consultation and notification procedures whenever a proposed activity, which is listed in Appendix 1, has potential transboundary impacts. ${ }^{68}$

Furthermore, some commentators indicate that the use of transboundary EIA and/or risk analysis should be undertaken in the light of customary international law obligations to prevent transboundary harm and to cooperate. ${ }^{69}$ Consequently, in the context of customary international law, EIA should stretch to cover a 'geographical scope according to the extent to which impacts are expected to extend, including transboundary implications' ${ }^{70}$

However, other commentators, such as John Knox, while not disagreeing that EIA should be used for these purposes, argue against this 'myth' ${ }^{71}$ They point out that while EIA can be used to evaluate the likelihood of transboundary harm and can also be used as a vehicle for notification and cooperation, $^{72}$ arrangements that facilitate EIA do not provide for a 'substantive prohibition against transboundary harm', nor do the arrangements apply to all potentially harmful activities. ${ }^{73}$ In particular, the fact that transboundary EIA and risk assessment mimic domestic procedures $^{74}$ means that international instruments offer procedural frameworks that guide the way decisions are made, ${ }^{75}$ but do not necessarily

\footnotetext{
68 Ibid., Article 5. For a discussion of the operation of the Convention, see E. Abrecht, 'Implementing the Espoo Convention in Transboundary EIA between Germany and Poland', 28:6 Environmental Impact Assessment Review (2008), 359.

${ }^{69}$ See J.H. Knox, n. 35 above, at footnote 33.

${ }^{70} \mathrm{H}$. Abaza and R. Hamwey, 'Integrated Assessment as a Tool for Achieving Sustainable Trade Policies’ 21:2-3 Environmental Impact Assessment Review (2001), 481, at 498.

${ }^{71}$ See J.H. Knox, n. 35 above; and see N.D. Hall, n. 36 above, at 700-723.

72 J.H. Knox, ibid.

73 Ibid.

${ }^{74}$ Ibid., at 291-2; see also J.J. de Boer, 'Bilateral Agreements for the Application of the UNECE Convention on EIA in a Transboundary Context' 19:1 Environmental Impact Assessment Review (1999), 85, at 90.

75 D. Dzidzornu 'Environmental Impact Assessment Procedure Through the Convention' 10:1 European Environmental Law Review (2001), 15; C. Bruch et al., 'Assessing the Assessments: Improving Methodologies for Impact Assessment In Transboundary Watercourses’ 23:3 International Journal of Water Resources Development (2007), 391.
} 
oblige States to take into account information from other States obtained through consultations or objections. ${ }^{76}$

If transboundary EIA and risk assessment were undertaken as part of customary international law, information and objections notified by other States would need to be taken into account as part of the exercise of due diligence. A State, for example, could hardly prevent or minimize transboundary harm without having regard to the knowledge gained by the notification and consultation process. ${ }^{77}$ Yet, provisions such as Article 14(c) of the CBD specify that States need to cooperate and exchange information, but stop short of imposing obligations to use that information in the conduct of a transboundary EIA.

As a consequence '.. . rather than being subject to a prohibition on significant harm ${ }^{78}$ decisions undertaken as a result of transboundary EIA and/risk analysis are made on the same basis as domestic EIA where the weight given to environmental matters is not settled. To this extent, 'obligations' with respect to prevention or minimization of transboundary harm as part of EIA remain soft and cannot be considered a sufficient exercise of due diligence for the purpose of customary international law. ${ }^{79}$ This approach is also mirrored in Guiding Principle 4 (The role of States) of the CBD Guiding Principles.

The unresolved status of EIA in international law is reinforced by the approach of the International Court of Justice (ICJ), ${ }^{80}$ which has on at least two occasions side-stepped the opportunity to comment on whether transboundary EIA has evolved into a principle of customary international law. The opportunities arose out the decisions in Nuclear Test Case (New

\footnotetext{
${ }^{76}$ See J.H. Knox, n. 35 above, at 293.

${ }^{77}$ Ibid., at 296-7.

${ }^{78}$ Ibid., at 304.

${ }^{79}$ Ibid., at 300.

${ }^{80}$ The International Court of Justice was established in June 1945 by the Charter of the United Nations. The court is the principle judicial arm of the United Nations.
} 
Zealand $v$ France) Request for an Examination of the Situation, (New Zealand $v$ France) $)^{81}$ and the Case Concerning the Gabčikovo-Nagymaros Project (Hungary $v$ Slovakia). ${ }^{82}$ In the former case, New Zealand asserted that EIA had become part of customary international law derived from 'widespread international practice'; ${ }^{83}$ while in the latter case both Hungary and Slovakia raised arguments based on scientific evidence detailing impact to the environment of the Danube region. ${ }^{84}$

In both cases, the majority of the court reached a decision without coming to grips with the principle of EIA. In New Zealand v France, the court specified that 'the present Order is without prejudice to the obligations of States to respect and protect the natural environment ${ }^{85}$ Yet the court did not specifically elaborate on the nature of those obligations; nor did the court address the argument of New Zealand with respect to whether EIA had become part of customary international law. Taking a similar approach, in Hungary $v$ Slovakia, the ICJ found that it was not necessary to consider the scientific arguments on EIA because the matter before the court turned on a strict application of treaty law. ${ }^{86}$ In this case, Vice President Weeramantry took a slightly different approach. Although his Excellency concurred with the majority, he also held that where developments have a potentially significant impact on the environment, States need to regard EIA, as a 'specific

${ }^{81}$ ICJ September 22, 1995 Request for an Examination of the Situation in Accordance with Paragraph 63 of the Court's Judgment of 20 December 1974 in the Nuclear Tests (New Zealand v. France) Case, Jurisdiction of the Court, Judgment (1995), I.C.J. Reports 288, available at

$<$ http://www.icj-cij.org/docket/index.php?p1=3\&p2=3\&k=cd\&case=97\&code=nzfr\&p3=3>.

${ }^{82}$ ICJ September 25, 1997, Case Concerning the Gabčikovo-Nagymaros Project (Hungary $v$ Slovakia, Jurisdiction of the Court, Judgment (1997), I.C.J. Reports 7, available at $<$ http://www.icj-cij.org/docket/index.php?p1=3\&p2=3\&k=8d\&case=92\&code=hs\&p3=4> (April 2009).

${ }^{83}$ New Zealand v France, Application Instituting Proceedings, 21 August 1995, Jurisdiction of the Court, Judgment (1995), I.C.J. Reports 1, at paragraph 73, available at $<$ http://www.icj-cij.org/docket/index.php?p1=3\&p2=3\&k=cd\&case=97\&code=nzfr\&p3=0>.

${ }^{84}$ See Hungary $v$ Slovakia, n. 82 above. See, for example, Chapter 5 of the Memorial of the Republic of Hungary (24 May 1994), found in Jurisdiction of the Court, Judgment (1995), I.C.J. Reports 1, available at <http://www.icj-cij.org/docket/files/92/10921.pdf>.

${ }^{85}$ See New Zealand $v$. France, n. 83 above, at paragraph 64.

${ }^{86}$ See Hungary v Slovakia, n. 84 above, at paragraphs 5, 58 and 59. 
application of the larger general principle of caution [that] embodies the obligation of continuing watchfulness and anticipation'. ${ }^{87}$ Although this statement falls short of elevating EIA to customary international law, his views on this development were, nevertheless, in the minority.

The decisions in New Zealand $v$ France 2 and Hungary $v$ Slovakia demonstrate hesitancy on the part of the ICJ even to comment specifically upon EIA much less to elevate it to a principle of customary international law. This approach is consistent with the views of those scholars who conclude that while the use of EIA is growing, it is not sufficiently widespread or clear to be regarded as part of customary international law. ${ }^{88}$

\section{QUARANTINE AND TRANSBOUNDARY HARM FROM IAS}

States have entered into numerous bilateral, regional and multilateral treaties to deal with quarantine matters. ${ }^{89}$ However, for the purposes of this paper, the discussion will centre on the 1997 International Plant Protection Convention (IPPC) $^{90}$ and the1924 International Agreement for the Creation at Paris of an International Office for Dealing with Contagious Diseases of Animals, and

${ }^{87}$ See Hungary $v$ Slovakia, ibid., separate opinion of Vice-President Weeramantry, at 111113, available at <http://www.icj-cij.org/docket/files/92/7383.pdf>.

${ }^{88}$ K. Bastmeijer and T. Koivurova, 'Conclusions: Globalisation of Transboundary Environmental Impact Assessment' in K. Bastmeijer and T. Koivurova (eds), Theory and Practice of Transboundary Environmental Impact Assessment (Martinus Nijhoff, 2008), at 356-357; and see J. O’Brien, International Law (Routledge-Cavendish, 2001), at 559.

${ }^{89}$ For example, see Agreement Concerning Co-Operation in the Quarantine of Plants and Their Protection Against Pests and Diseases (Sofia, 14 December 1959), Preamble. The Convention entered into force 19 October 1960. see alsoTreaty of Commerce and Navigation with a final Protocol and Additional Protocol Between Albania and the Kingdom of the Serbs, Croats and Slovenes (Belgrade, 22 June 1926). The Treaty entered into force on 6 June 1929. See also Treaty of Commerce and Navigation made between Denmark and Finland, (Helsinki, 3 April 1923). The treaty entered into force on 21 December 1923.

${ }^{90}$ International Plant Protection Convention (Rome, 17 November 1997). The Convention entered into force 2 October 2005 (IPPC). The Convention had 170 Parties as of February 2009. 
Annex (OIE). ${ }^{91}$ These two treaty systems enjoy the widest membership of the quarantine treaties and comments made with respect to these treaties will also be relevant to other quarantine regimes.

The 1997 IPPC emphasizes preventing the entry, establishment and spread of pests and diseases of plants, that in the convention are described as a 'regulated pest'. ${ }^{92}$ When implementing measures, States should ensure their measures are technically justified ${ }^{93}$ which means that measures should be based on pest risk analysis, or other 'comparable examination and evaluation of available scientific information'. 94 'Pest risk analysis' encompasses measures based on international standards such as those developed by the Commission on Phytosanitary Measures (the Commission). ${ }^{95}$ The Commission is administered by the IPPC and membership is open to all IPPC members, ${ }^{96}$ each of whom have one vote. ${ }^{97}$ The Commission has developed a number of standards dealing with pest risk analysis ${ }^{98}$ and phytosanitary treatments for regulated pests. ${ }^{99}$ 'Comparable' procedures would appear not to be limited to standards developed by the Commission and the concept opens the possibility of States using other standards and guidelines, such as, those formulated by the CBD Guiding Principles.

Animal regulation is dealt with under the auspices of the Office International des Epizooties (OIE), otherwise known as the World Organisation for Animal

${ }^{91}$ International Agreement for the Creation at Paris of an International Office for Dealing with Contagious Diseases of Animals, and Annex (Paris, 25 January 1924). The treaty entered into force on 12 January 1925. The organization is known as the OIE and as of February 2009 had 172 members.

${ }^{92}$ See IPPC, n. 90 above, Article II.

${ }^{93}$ Ibid., Articles VII(2)(a) and VII(3).

${ }^{94}$ Ibid., Article II.

${ }^{95}$ Ibid., Articles XI(3)and Article XI(2).

${ }^{96}$ Ibid., Article XI(3).

${ }^{97}$ Ibid., Article XI(4).

${ }^{98}$ Secretariat of the International Plant Protection Convention, International Standards for Phytosanitary Measures ISPM No 11: Pest Risk Analysis for Quarantine Pests Including Analysis of Environmental Risks and Living Modified Organisms 2004 (FAO, 2006).

${ }^{99}$ Secretariat of the International Plant Protection Convention, International Standards for Phytosanitary Measures ISPM No 28: Phytosanitary Treatments for Regulated Pests 2007 (FAO, 2007). 
Health. The OIE focuses on collecting and disseminating information on outbreaks of animal diseases and providing members with guidance on how best to maintain animal health and safety. ${ }^{100}$

A major part of this function is the publication of animal health codes, ${ }^{101}$ which are formulated as principles, guidelines and recommendations that standardize health and quarantine regulations for animals and animal products. ${ }^{102}$ Akin to the IPPC standards, the OIE Codes recommend the use of risk analysis.

To the extent that the OIE Codes and IPPC phytosanitary standards target the avoidance of introducing pests and diseases across international borders, ${ }^{103}$ the instruments are concerned with preventing transboundary harm. Indeed, in accordance with the IPPC, States are given great latitude to prevent entry of any species or 'biotype of plants animals or pathogenic agents injurious to plants or plant products'. ${ }^{104}$ Moreover, membership of the OIE is predicated on States monitoring their territory and notifying the OIE of outbreaks of disease and pestilence allowing the OIE to warn members of outbreaks of disease. ${ }^{105}$

However, neither regime broaches broader transboundary issues. For example, while the Commission on Phytosanitary Measures has at the time of writing developed 31 standards, no standard specifically deals with the type of transboundary harm envisaged by Guiding Principle 4(c) of the CBD

100 See International Agreement for the Creation at Paris of an International Office for Dealing with Contagious Diseases of Animals, n. 91 above, Annex, Article 4. The Annex is the Organic Statute of the International Office for Dealing with Contagious Diseases of Animals. See discussion in FAO, Multilateral Trade Negotiations on Agriculture, A Resource Manual (FAO, 2000), section 6.6.

${ }^{101}$ Aquatic Animal Health Code $200811^{\text {th }}$ ed. (OIE Paris, 2008); and Terrestrial Animal Health Code 2008, $17^{\text {th }}$ ed. (OIE Paris, 2008).

${ }^{102}$ See Secretariat of the International Plant Protection Convention, n. 98 above, at section 6.9 .

${ }^{103}$ See Terrestrial Animal Health Code 2008, n. 101 above, introductory explanation.

${ }^{104}$ See IPPC, n. 90 above, Article VII and Article II.

${ }^{105}$ This role of the OIE is set out in Organic Statute of the International Office for Dealing with Contagious Diseases of Animals, n. 100 above, Article 5. 
Guiding Principles (on the role of States). Nor do the regimes necessarily cover all species. The OIE codes, for instance, are primarily aimed at animals and animal products that are traded and do not deal with some species such as reptiles. ${ }^{106}$ As a result, while the IPPC and OIE have developed a large body of recommendations and guidelines utilizing risk analysis, their processes do not cover all types of transboundary harm. However, at the same time, both regimes are permissive in the sense that States may implement stricter measures than those found in IPPC and OIE standards and guidelines. What may be more problematic for States is that where the prevention of transboundary harm from alien species involves international trade, States also need to ensure that their regimes comply with the rules of international trade law.

\section{THE WTO AND TRANSBOUNDARY HARM FROM IAS}

The international trade law regime is vast, encompassing over three hundred free or preferential trade agreements. ${ }^{107}$ Of these, the World Trade Organization (WTO) has been chosen as representative of trade and IAS issues due primarily to its substantial membership. ${ }^{108}$ Moreover, other free trade agreements of WTO members regularly affirm existing rights and obligations under the WTO. ${ }^{109}$

${ }^{106}$ OIE standards can, however, be adapted. See AQIS, Import Risk Analysis Paper for Live Crocodilians and their Eggs (AQIS, 2000), which was adapted from OIE standards aimed at the trade in birds.

${ }^{107}$ The WTO web site indicates that as of July 2007 more than 380 regional trade agreements had been notified to it. See WTO, Regional Trade Agreements (WTO, undated), available at $<$ http://www.wto.org/english/tratop_e/region_e/region_e.htm>.

${ }^{108}$ For example, WTO has 153 members, see n 110 below. Other regimes such as the North American Free Trade Agreement (NAFTA) have three members (North American Free Trade Agreement (Washington, Ottawa, Mexico City, 17 December 1992); the European Union has 27 members as of February 2009. The agreement establishing the European Union, the Treaty on European Union (Maastricht 7 February 1992). [1992] OJ C 191.

${ }^{109}$ See Australia-US Free Trade Agreement, (Washington, 18 May, 2004). Article 7.3 affirms the provisions of the Agreement on the Application of Sanitary and Phytosanitary Measures (Marrakesh, 15 April 1994) (SPS Agreement). See also nn. 110 and 112 below. 
The WTO was created on 1 January 1995 in accordance with the Marrakesh Agreement Establishing the World Trade Organization. ${ }^{110}$ That Agreement contains a number of annexes, including GATT $1994^{111}$ and the Agreement on the Application of Sanitary and Phytosanitary Measures (SPS Agreement). ${ }^{112}$ The latter regulates the design and implementation of quarantine measures in international trade. It also provides a primary source of rights and obligations for WTO members, while GATT provides a general basis for rights and obligations where the SPS Agreement does not apply. ${ }^{113}$

\subsection{Overview of the Agreement on the Application of Sanitary and Phytosanitary Measures}

The SPS Agreement is designed to elaborate on rules for the administration of national quarantine legislation in international trade. ${ }^{114}$ It is a free-standing agreement ${ }^{115}$ that sets out binding requirements for plant, animal and food health and safety and underpins these with a set of essential principles, found in its Articles 2 to $10 .{ }^{116}$ Members need to ensure that their quarantine measures adhere either to international standards, ${ }^{117}$ or are based on a risk assessment. ${ }^{118}$ Approved international standards are those developed by three

${ }^{110}$ Marrakesh Agreement establishing the World Trade Organization (Marrakesh, 15 April 1994). As of February 2009 the WTO has 153 members.

${ }^{111}$ Upon the commencement of the WTO, on 1 January 1995, GATT 1947 became inoperative and its provisions were incorporated into GATT 1994. See General Agreement on Tariffs and Trade 1994 (Marrakesh, 15 April, 1994), Article 1(a).

${ }^{112}$ The Agreement on the Application of Sanitary and Phytosanitary Measures (Marrakesh, 15 April 1994) (SPS Agreement).

${ }^{113}$ Agreement Establishing the WTO, n. 110 above, Article 1A; SPS Agreement, ibid., Article 2.4.

${ }^{114}$ SPS Agreement, ibid., Articles 3.5 and 12.1.

115 WTO DS 18 August 1997, EC Measures Concerning Meat and Meat Products (Hormones) Complaint by Canada Report of the Panel (EC - Hormones Panel Report Canada), WT/DS48/R/CAN, at paragraphs 8.37-8.44.

${ }^{116}$ For a discussion of the SPS Agreement, see J. Pauwelyn, 'The WTO Agreement and Phytosanitary (SPS) Measures as Applied in the First Three SPS Disputes' 2:4 Journal of International Economic Law (1999) 641.

${ }^{117}$ See SPS Agreement, n. 112 above, Article 3.2.

${ }^{118}$ Ibid., Articles 2.2 and 5. 
nominated standard-setting bodies: ${ }^{119}$ the Codex Alimentarius, ${ }^{120}$ the $\mathrm{OIE}^{121}$ and the IPPC. ${ }^{122}$ Domestic measures based on these standards are presumed to be WTO-consistent. This feature links the international quarantine regime closely with the international trade law regime. In addition, trade issues were also a major consideration in the negotiation of the CBD Guiding Principles and the CBD has concluded a joint work plan with the IPPC. ${ }^{123}$ Consequently, the three regimes are not isolated.

The SPS Agreement also requires that measures should not exceed a State's appropriate level of protection (ALOP). ${ }^{124}$ The ALOP is defined in the SPS Agreement as: 'the level of protection deemed appropriate by the member'. ${ }^{125}$ It determines what level of risk is acceptable for a member and essentially operates as an upper ceiling, beyond which measures cannot be implemented. ${ }^{126}$ In the context of transboundary harm, it is not clear whether WTO members may take into account the likelihood of damage to other States when setting their ALOP. In the case of the ruddy duck, for example, it is questionable whether the UK could set its ALOP by reference to the chances of the ruddy duck establishing in Europe.

${ }^{119}$ Ibid., Annex A, paragraph 3.

${ }^{120}$ Ibid., Annex A, Article 3(a). The Codex Alimentarius Commission was created in 1963 by FAO/WHO. As of February 2009 it has 181 members.

${ }^{121}$ Ibid., Annex A, Article 3(b).

${ }^{122}$ Ibid., Annex A, Article 3(c).

${ }^{123}$ See for example, FAO, Interim Commission on Phytosanitary Measures, Memorandum of Cooperation between the CBD and the IPPC, Sixth Session, April 2004, Document ICPM 04 INF/15. Available from $<$ https://www.ippc.int/servlet/BinaryDownloaderServlet/30481_ICPM04inf15.pdf?filename= 1073577233448_ICPM04_INF_15.pdf\&refID=30481> (last visited May 2009).

${ }^{124}$ See SPS Agreement, n. 112 above, Article 2.2.

${ }^{125}$ Ibid., Annex A, Article 5. See also J. Atik, 'The Weakest Link: Demonstrating the Inconsistency of 'Appropriate Levels of Protection' in Australia - Salmon' 24:2 Risk Analysis (2004), 483; S. Henson 'The 'appropriate level of protection': a European perspective', in K Anderson et al., (eds) The Economics of Quarantine and the SPS Agreement (Centre for International Economic Studies Adelaide and AFFA Biosecurity Australia, 2001), 105; Parliament of Australia (Senate): Senate Committees: An Appropriate Level of Protection, The Importation of Salmon Products (Commonwealth of Australia, 2000).

${ }^{126}$ G. Stanton, 'The Multilateral Trading System and SPS Agreement' in Quarantine and Market Access, Forum Proceedings 6-7 September 2000, Department of Agriculture \& Forestry- Canberra Australia (2000), 73, at 75-6. 
As a result, where prevention of transboundary environmental harm cannot be taken into account in the setting of an ALOP, neither can it be reflected in SPS measures. ${ }^{127}$ Unlike the IPPC and OIE, which are permissive, the SPS Agreement is prohibitive in the sense that measures that do not conform to its rules cannot be maintained. ${ }^{128}$ Therefore, the meaning of an SPS measure is significant in identifying the jurisdictional sweep of the SPS Agreement and the consequential validity of measures.

\subsection{The meaning of an SPS Measure}

Article 1 of Annex A defines an SPS measure widely as any measure applied:

(a) to protect animal or plant life or health within the territory of the Member from risks arising from the entry, establishment or spread of pests, diseases, diseasecarrying organisms or disease-causing organisms;

(c) to protect human life or health within the territory of the Member from risks arising from diseases carried by animals, plants or products thereof, or from the entry, establishment or spread of pests; or

(d) to prevent or limit other damage within the territory of the Member from the entry, establishment or spread of pests.

In European Communities - Measures Affecting the Approval and Marketing of Biotech Products (Biotech Products), ${ }^{129}$ the EC had asserted that to be classified as an SPS measure, the measure had to have an objective or purpose within the ambit of the SPS Agreement. ${ }^{130}$ As the SPS Agreement was not negotiated to deal with environmental issues, the EC further contended that the SPS Agreement was not relevant where measures were

127 See SPS Agreement, n. 112 above, Article 2.2.

128 WTO AB 20 October 1998, Australia - Measures Affecting Importation of Salmon (Australia - Salmon), WT/DS/18/AB/R, at paragraph 136; WTO DS 23 June 2005, Japan Measures Affecting the Importation of Apples, Recourse to Article 21.5 (Japan - Apples 21.5) WT/DS245/RW, at paragraphs 8.39-8.71, 8.119-8.121 and 9.1.

129 WTO Panel 29 September 2006, European Communities - Measures Affecting the Approval and Marketing of Biotech Products (Biotech Products) WT/DS/291, WT/DS/292 and WT/DS/293, at paragraph 7.158.

${ }^{130}$ Ibid., at paragraph 7.151. See also European Communities - Measures Affecting Biotech Products First Written Submission the Approval and Marketing of Biotech Products by the European Communities DS/291, DS/292, DS/293 First written submission by the European Communities (17 May 2004), at paragraphs 389-433. 
designed to achieve environmental objectives. ${ }^{131}$ Had these arguments succeeded, it would have meant that SPS measures to protect the environment would be adjudicated elsewhere, perhaps outside the WTO, or under other WTO instruments, such as the Article XX exceptions to GATT. However, the Panel of the $\mathrm{WTO}^{132}$ ruled that the definition of an SPS measure found in Annex A of the SPS Agreement is extensive enough to cover risks to the environment. ${ }^{133}$

This finding gives the concept of an SPS measure an expansive meaning and also effectively ensures that SPS measures implemented to protect biodiversity from the threat of alien species also come within the ambit of the SPS Agreement. However, the decision referred to risks enumerated in Annex A and the Annex does not specifically address prevention of transboundary harm. ${ }^{134}$ Rather, Annex A refers to risks or harm occurring 'within the territory of the member'.

As used in Annex A, the phrase 'within the territory of the member', is open to at least three interpretations: first, a measure is not a proper SPS measure, unless the object of protection is located within the territory of a WTO member; second, a measure is an SPS measure whenever the measure is implemented within the territory of the member enacting the law, irrespective of the location of the object of protection; and third, the phrase limits the jurisdiction of the SPS Agreement to SPS measures where the object of protection is located within the territory of the member enacting the law. Otherwise the validity of the law is determined by a different method, such as GATT.

${ }^{131}$ European Communities, ibid., at paragraph 416; and see Biotech Products, n. 131 above, at paragraphs 7.151 and 7.198.

${ }^{132}$ Disputes under the WTO are governed by the Understanding on Rules and Procedures Governing the Settlement of Disputes (DSU), [1995] ATS no 8.

${ }^{133}$ See Biotech Products, n. 131 above, at paragraphs 7.158 and 7.365 .

${ }^{134}$ Ibid., at paragraph 7.158. 
These three potential interpretations represent vastly different understandings of the place of transboundary issues within the WTO. The first interpretation invalidates the measure out of hand. The second and third interpretations do not automatically invalidate the measure, although the measure must still be validated pursuant to the WTO. In the second interpretation, the validity of the measure would be determined in accordance with the SPS Agreement; while in the case of the third interpretation, the measure would arguably be outside the jurisdiction of the SPS Agreement, but within the jurisdiction of other WTO agreements, such as the GATT.

In the second case, the measure would be adjudicated upon the basis of the SPS Agreement. This represents a real likelihood that the measure would be declared invalid. To start with, international standards so far accepted under the SPS Agreement do not address the rights or obligations of one State to take into account invasive species that could spread from their territory into the territory of other States. ${ }^{135}$ In addition, it is not clear whether prevention of transboundary environmental harm is a valid consideration to be taken into account in setting an ALOP, and if it is not, then it cannot be reflected in measures. The third interpretation is based on the premise that transboundary matters are governed by the Article XX exceptions to GATT, and in particular Article XX(g).

\subsection{Article XX Exceptions to GATT}

Article XX of the GATT provides exceptions for measures that would otherwise breach GATT rules and principles - including principles of non-

135 'Invasive Alien Species: Comprehensive review on the efficacy of existing measures for their prevention, early detection, eradication and control' (UNEP/CBD/SBSTTA/6/7, 20 December 2000), at paragraph 42. 
discrimination ${ }^{136}$ and proscriptions against quantitative restrictions by way of quotas, licences and other restrictions. ${ }^{137}$

Articles $\mathrm{XX}(\mathrm{b})$ and $\mathrm{XX}(\mathrm{g})$, specify that:

Subject to the requirement that such measures are not applied in a manner which would constitute a means of arbitrary or unjustifiable discrimination ... or a disguised restriction on international trade, nothing in this Agreement shall be construed to prevent the adoption or enforcement by any contracting party of measures:

(b) necessary to protect human, animal or plant life or health;

(g) relating to the conservation of exhaustible natural resources if such measures are made effective in conjunction with restrictions on domestic production or consumption;

The proviso, or 'Chapeau' to the Article, found in the first four lines, provides an overriding discrimination-based test for determining whether measures satisfy the Article XX exceptions. The Chapeau addresses, not so much the specific contents of measures, but rather the manner in which measures are applied $^{138}$ ensuring that measures are neither applied arbitrarily, nor are a disguised restriction on international trade.

Articles $\mathrm{XX}(\mathrm{b})$ and $\mathrm{XX}(\mathrm{g})$ also permit implementation of national policy where it is applied in a non-discriminatory way. A State relying on Article $\mathrm{XX}(\mathrm{b})$, for example, needs to demonstrate that the measure falls 'within the

${ }^{136}$ General Agreement on Tariffs and Trade (Geneva, 30 October, 1947), Articles I and III. The Agreement entered into force 1 January 1948. See also D. Esty, Greening the GATT: Trade, Environment and the Future (Institute for International Economics, 1994), at 245-6; and see P. Van Den Bossche, The Law and Policy of the World Trade Organization Text, Cases and Materials (Cambridge University Press, 2005), chapter 4.

${ }^{137}$ See GATT, n. 138 above, Article XI; and see D. Neven and J. Weiler, 'Japan - Measures Affecting the Importation of Apples (AB-2003-4): One Bad Apple? A Comment', in H. Horn and P. C. Mavroidis (eds), The American Law Institute Reporters' Studies on WTO Case Law: Legal and Economic Analysis (Cambridge University Press, 2003), 881.

${ }^{138}$ WTO AB 29 April 1996, United States - Standards for Reformulated and Conventional Gasoline, WT/DS2/AB/R, at paragraph IV; and WTO AB 12 October 1998, United States Import Prohibition of Certain Shrimp and Shrimp Products (US-Shrimp), WT/DS/58/AB/R, at paragraphs 158-159. 
range of policies designed to protect human, animal or plant life or health,139 and, that the measure achieves a sense of proportionality between the risk under consideration and the trade restraint involved. ${ }^{140}$

In a like manner, conservation measures under Article XX(g) should not be: '... disproportionately wide in ... scope and reach in relation to the policy objective of protection and conservation'. ${ }^{141}$ Moreover, pursuant to Article $\mathrm{XX}$ (g) measures need to be implemented in an even-handed manner, so that comparable restrictions are placed on both imported and domestic products. ${ }^{142}$ Cases on Articles XX(b) and XX(g) have considered the question of extraterritorial application of laws, rather than the question of prevention of transboundary harm

An extraterritorial application of laws concerns the application of laws extending beyond the territory of a member. Often these laws are implemented unilaterally and are designed to influence or coerce other States to adhere to policy objectives formulated by the implementing State. ${ }^{143}$ Such laws need to be distinguished from laws designed to prevent transboundary harm discussed in this paper. The latter will be applied within the territory of a member in order to prevent environmental harm emanating from that State. Despite this difference, GATT and WTO cases that deal with extraterritorial

${ }^{139}$ WTO DS 29 January 1996, United States- Standards for Reformulated and Conventional Gasoline (United States-Gasoline), WT/DS2/R, at paragraph 6.20.

${ }^{140}$ WTO AB 12 March 2001 European Communities - Measures Affecting Asbestos and Asbestos-Containing Products (EC-Asbestos), WT/DS135/AB/R (Report of the Appellate Body, 2001), at paragraphs 164-175; see also T.L. McDorman, 'The GATT Consistency of US Fish Import Embargoes to Stop Driftnet Fishing and Save Whales, Dolphins and Turtles' 24:3 George Washington Journal of International Law and Economics (1991), 479; W. Snape III and N. Lefkovitz, 'Searching for GATT's Environmental Miranda: Are 'Process Standards’ Getting 'Due Process?’ 27:3 Cornell International Law Journal (1994), 777, at 797.

${ }^{141}$ See US-Shrimp, n. 140 above, at paragraph 141.

${ }^{142}$ See United States-Standards for Reformulated and Conventional Gasoline, n. 140 above, at paragraphs 20-21.

${ }^{143}$ GATT Panel 3 September 1991 United States - Restrictions on Imports of Tuna (Tuna I) Report of the Panel DS21/R, at paragraphs 5.27-5.28; GATT Panel 16 June 1994 United States - Restrictions on Imports of Tuna 1994 (Tuna 11), Report of the Panel DS29/R, at paragraphs 5.37-5.39. 
issues remain important as they are helpful to understanding the position of the WTO on the validity of national laws that protect territory and biodiversity beyond national borders.

Three cases involving Articles XX(b) and XX(g), United States Restrictions on Imports of Tuna 1991(Tuna I), United States - Restrictions on Imports of Tuna 1994 (Tuna II) ${ }^{144}$ and US - Shrimp have raised a direct territorial argument. Both Charnovitz and Condon have argued that extraterritorial concerns are valid considerations pursuant to the Article XX GATT exceptions. ${ }^{145}$ However, Condon points out that one of the main differences between Article XX(b) and Article XX(g) is the 'territorial reach' of each provision. ${ }^{146}$ His view is that Article $\mathrm{XX}(\mathrm{b})$ is designed to validate measures protecting the territory of the member enacting the law, ${ }^{147}$ while Article XX(g) could apply to laws designed to prevent environmental harm located elsewhere. If Condon's view is correct, it means that Article XX(b) would rarely apply to IAS. The definition of an SPS measure pursuant to the SPS Agreement covers the same ground as Article XX(b) and the SPS Agreement takes precedence.

This still leaves a consideration of Article XX(g). Although early decisions on this Article took a conservative approach to the question of territorial issues, ${ }^{148}$ the Appellate Body in US-Shrimp took a more liberal view:

We do not pass upon the question of whether there is an implied jurisdictional limitation in Article XX(g), and if so, the nature or extent of that limitation. We note only that in the specific circumstances of the case before us, there is a sufficient nexus between the migratory and endangered marine populations involved and the United States for purposes of Article XX(g). ${ }^{149}$

\footnotetext{
${ }^{144}$ United States-Restrictions on Imports of Tuna 1994 (Tuna II), ibid.. Journal of World Trade Law (1991), 37; B. Condon 'GATT Article XX and Proximity of Interest: Determining the Subject Matter of Paragraphs b and g', 9:2 University of California Los Angeles Journal of International Law and Foreign Affairs (2004), 137.

146 B. Condon, ibid., at 144-147.

147 Ibid.

148 See Tuna I, n. 145 above, at paragraphs 5.30-5.32.

${ }^{149}$ See US-Shrimp, n. 140 above, at paragraph 133.
}

145 S. Charnovitz, 'Exploring the Environmental Exceptions in GATT Article XX', 25:5 
While this Statement is equivocal, the Appellate Body did not reject measures out of hand merely because they had an extraterritorial component. Because little guidance was given on the meaning of a 'sufficient nexus', the matter remains open to interpretation. A narrow interpretation of the word 'sufficient' may mean that the degree of connection between the measure and national objectives is set so high that the territorial or transboundary component would restrict the reach of the measure. However, the important point is that the WTO has signified a responsive attitude towards transboundary concerns. Yet, at this stage, it is still not certain whether GATT or the SPS Agreement will apply in cases of transboundary harm caused by IAS and this point could be decisive.

\section{CONCLUSION}

In accordance with customary international law, States are under broad obligations to prevent transboundary harm and to cooperate. Theoretically these obligations apply as much to damage caused by IAS as to other forms of environmental harm. Yet, in reality implementing these generalized customary law obligations has proved challenging for States in the case of IAS.

A potential means of making customary international law operational is for States to use transboundary EIA and risk analysis. However, provisions found in instruments from international environmental law, international quarantine and international trade law that deal with transboundary harm caused by IAS, remain largely soft. In addition, States themselves generally favour soft law approaches such as exchange of information, notification of activities and cooperation - a situation that is understandable given resource constraints faced by most, if not all States. 
However, if States are to be encouraged to prevent or minimise transboundary harm caused by IAS, international law needs to provide clearer guidance on the priority and weighting to be given to the protection of biodiversity. Iinternational law also needs to be consistent across the three major regimes that relate to IAS. Otherwise, gaps, deficiencies and inconsistencies can potentially defeat strategic objectives and permit the continuance of transboundary harm caused by IAS.

Sophie Riley is a lecturer in law at the University of Technology Sydney. Her teaching and research interests centre on international environmental law and corporate law. Most recently, Sophie has completed a PhD titled 'Invasive Alien Species and The Protection of Biodiversity: the Role of Quarantine Laws in Resolving Inadequacies in the International Legal Regime'. She has also co-authored a bi-lingual corporate law text that was due for publication in Australia in May 2009. The assistance of Dr Stathis Palassis and Tracey Booth, as well as helpful comments by the anonymous referees is gratefully acknowledged. All errors remain my own. 